\title{
SOUTH AMERICAN AND FLORIDIAN DISJUNCTS IN THE SONORAN GENUS COMPSOCRYPTUS (HYMENOPTERA: ICHNEUMONIDAE).
}

\author{
By Charles C. Porter ${ }^{1}$ \\ Department of Biological Sciences, Fordham University \\ Bronx, NY 10458
}

\section{INTRODUCTION}

Taxonomy

Most Compsocryptus may be recognized at a glance by their elegantly yellow banded brown or black wings, large and anteriorly wide areolet, short and weak notauli, axillus intermediate in position between the anal margin of the hind wing and the submediella, strong ventro-lateral carina on postpetiole, and long, upcurved ovipositor.

My concept of this genus agrees, as to species included, with Townes' most recent definition (1969:203-4). Several of Townes' diagnostic features, however, do not apply to the Compsocryptus I have examined (C. fasciipennis, C. fuscofasciatus, C. melanostigma, C. texensis, and C. xanthostigma). All Compsocryptus I have seen possess a sharp and strong subvertical groove externo-ventrally near the base of the hind coxa, while Townes describes the hind coxa as "without a groove"(1969:203). All Compsocryptus examined by me have, in the female only, a prominent crescentic to subtriangular baso-lateral flange at the base of the petiole, while Townes maintains that the petiole is "without a lateral tooth at the base" (1969:203). Compsocryptus forms a compact genus whose species, despite their far-flung and discontinuous distribution, seem unusually homogeneous in color and structure. I thus suspect that all members of the genus will turn out to have a basal first gastric projection in the female and a strong hind coxal groove.

\footnotetext{
${ }^{1}$ Research Associate, Florida State Collection of Arthropods, Florida Department of Agriculture and Consumer Services, Division of Plant Industry, P.O. Box 1269, Gainesville FL 32602.

Manuscript received by the editor May 28, 1985
} 
Relationships

Compsocryptus displays close affinity to Trachysphyrus, Aeliopotes, Joppidium, and Lanugo. Superficially, in color, size, habitus, and many details of geographic distribution, Lanugo especially parallels Compsocryptus. However, the phylogenetic connection seems distant, since Lanugo has only a weak groove at the base of the hind coxa, the axillus vein closer to the hind margin of the wing than to the submediella, and the ovipositor straight and shorter than in Compsocryptus. The South American Trachysphyrus [now regarded as including only the Imperialis group, as defined by Porter (1967:275-319)] seems directly associated with Compsocryptus. Important characters that separate Trachysphyrus include: dark but never pale banded wings; body color usually metallic blue, green, or purple; female flagellum scarcely flattened below; notauli usually (not always) extending beyond the middle of the mesoscutum; surface of mesoscutum shining, never extensively mat; 1st gastric tergite without a baso-lateral expansion; and 2nd gastric tergite in many species smooth and polished (in numerous others mat). Aeliopotes paitensis (Porter, 1986) in some ways (especially the petiolar tooth) seems annectant between Compsocryptus and Trachysphyrus but in other features (epomial development) is aberrant and deserves generic status. Finally, Joppidium seems to be a direct offshoot of Compsocryptus. Joppidium is more slender than Compsocryptus (postpetiole at least 1.5 as long as wide), lacks a ventro-lateral carina on the 1st gastric tergite, and has the female flagellum more strongly flattened below toward apex. Some of its species have a baso-lateral tooth on the petiole and yellow banded wings, as in Compsocryptus. Joppidium also parallels its relative in distribution, with numerous Sonoran species, several which extend (but not disjunctly) into the southeastern United States, and with an isolated species group in subtropical Brasil and north Argentina (no representatives in the Peruvian Coastal Desert).

\section{Biogeography and Ecology}

Compsocryptus belongs to the Sonoran Biogeographic category (Porter 1980:25-7). Possibly the genus evolved during the last half 
of the Tertiary somewhere in southwestern North America. Certainly, its xerophilous species would have adapted well to the increasingly drier climates of post-Oligocene times and to the microphyll and sclerophyll Madro-Tertiary Geoflora which then overspread the ever-rising Sierra Madre and Rocky Mountains. On the other hand, Compsocryptus may have originated in western and southern South America, where so many of its relatives are centered today. Here, the Miocene climate paralleled that of the Sonoran region. By the end of the Miocene the Argentine pampas had become well developed, composites and other dry-adapted plants of open habitats were radiating vigorously, and long dry seasons began to characterize the middle latitudes as a result of the reduced rainfall and "the ever-increasing rain-shadow effect of the rising Andes" (Solbrig 1976:22-3). Thus arose the Chaco, an austral Sonora.

Whatever may have been its genesis, Compsocryptus today is centered in the western United States and northern México (15 species). It also has 3 remarkable disjuncts: $C$. fasciipennis in tropical Florida and Cuba, C. fuscofasciatus in the Peruvian Coastal Desert, and $C$. melanostigma in north Argentina and nearby areas in Paraguay and Brazil.

Even the most geographically remote species of Compsocryptus differ only in apparently minor features of color and sculpture. This fact may suggest that the disjunctions noted above arose in comparatively recent times. Both the increasing aridity of the later Tertiary and xerothermic episodes within the Pleistocene probably allowed semiarid communities (Thorn Scrub, Subtropical Deciduous Forest, etc.) to range almost uninterruptedly from the southeastern United States to Argentina. Wet periods during the Pleistocene (glacial maxima at higher latitudes) would have favored the expansion of forests and probably caused the fragmented distribution that is observed among modern Compsocryptus species.

For example, "during a past period of low rainfall a prairie type flora, such as is found today in Texas and Arizona, was able to extend its range into the eastern United States, and remnants of this flora reflecting dry conditions still exist on parts of the west coast of Florida and on Big Pine Key" and other lower Florida Keys (Spencer and Stegmaier 1973:13). Such dry periods occurred both in the Pleistocene and in the climatically unsettled late Tertiary. They 
allowed eastward expansion by a whole complex of Sonoran Biota, from Opuntia, Cereus, Acacia and other xerophytes, to insects like Compsocryptus fasciipennis, several species of Joppidium, Lanugo retentor, Derocentrus longicaudis, Eiphosoma dentator (all Ichneumonidae), Eumenes smithii (Eumenidae), Stictiella (Sphecidae) and even to vertebrates, such as the reptiles Crotalus, Sistrurus, Pituophis, Sceloporus, and Gopherus.

Concurrently, similar physio-climatic events could have produced the plausibly vicariant differentiation of Compsocryptus fuscofasciatus and C. melanostigma in South America. As discussed under $C$. melanostigma, the common ancestor of these two species may have ranged in Chaco vegetation from Argentina to coastal Perú at a time before the Andes were high enough at this latitude to impede east-west exchange of lowland biota.

As intimated throughout the above discussion, Compsocryptus prefers semiarid or arid environments, but also may be abundant in open, degraded subtropical humid forests. Compsocryptus melanostigma, for example, has been cited from the very wet Selva Tucumano-Boliviana and Selva Misionera in Argentina. However, the majority of these forest records are from ecotones between forest and Chaco or from sites in the first stages of secondary succession (logging roads, clearings, windfalls, etc.). This fact demonstrates how precarious is the present-day equilibrium between forest and scrub (Selva and Chaco). Almost all modern forests are surrounded by drier environments, whose aggressive biota tends to encroach with the slightest ecological perturbation. Compsocryptus melanostigma in Argentina and C. fasciipennis in south Florida are among the many indicator species of these often anthropogenic and usually disastrous environmental changes, from forest to scrub and finally to desert.

\section{Hosts}

Compsocryptus are among the most common, conspicuous, and frequently collected of New World Ichneumonidae. Nonetheless, practically nothing is known about their host relationships. Only Compsocryptus melanostigma has been reared. It parasitizes noctuid moths of the genera Alabama and Pseudaletia. Alabama larvae feed on cotton and pupate in rolled leaves. Pseudaletia larvae feed at night on many kinds of grains and grasses, hiding by day under 
clods of earth or in other slightly subsurface shelters. Pseudaletia pupae are made in the ground. These data explain why females of $C$. melanostigma most often are collected on the ground or from low vegetation. Other Compsocryptus species occur in similar microhabitats and probably parasitize comparable hosts.

\section{Collections}

Listed below in alphabetic order are the collections in which material from this study has been or is to be deposited. Institutional collections are designated by the name of the city where they are located. Individual collections are referred to by the surnames of their owners.

CAMBRIDGE. Museum of Comparative Zoology, Harvard University, Cambridge, MA 02138.

COLlege Station. Department of Entomology, Texas A \& M University, College Station, TX 77843

GAINESVille. Florida State Collection of Arthropods, Bureau of Entomology, Division of Plant Industry, Florida Department of Agriculture and Consumer Services, P. O. Box 1269, 1911 SW 34th Street, Gainesville, FL 32602.

LAWRENCE. Department of Entomology, Snow Entomological Museum, The University of Kansas, Lawrence, KS 66045. PORTER. Collection of Charles C. Porter, 301 North 39th Street, McAllen, TX 78501.

TOWNES. American Entomological Institute, c/o Dr. Virendra Gupta, Bureau of Entomology, Division of Plant Industry, Florida Department of Agriculture and Consumer Services, Gainesville, FL 32602.

\section{Genus COMPSOCRYPTUS}

Cryptoideus Ashmead, 1900. Proc. U. S. Natl. Mus. 23: 42. Type: Cryptus purpuripennis Cresson.

Compsocryptus Ashmead, 1900. Proc. U. S. Natl. Mus. 23: 43. Type: Cryptus calipterus Say.

Callicryptus Ashmead, 1900. Proc. U. S. Natl. Mus. 23: 43. Type: (Cryptus "fasciatus" Brullé) = fasciipennis Brullé.

Stictocryptus Cameron, 1908. Trans. Amer. Ent. Soc. 34: 243. Type: (Cryptus "fasciatipennis" Brullé) = fasciipennis Brullé.

Sophocryptus Mallo, 1961. Idia 165: 17. Nomen nudum. 
Fore wing 7.2-13.0 mm long. Wings usually dark with yellow transverse bands. Female flagellum somewhat widened and flattened below on apical 0.3. Male flagellum with linear tyloids on many intermediate segments. Mandible usually moderately broad with lower tooth slightly shorter than upper tooth (rarely long and slender with lower tooth much shorter than upper). Clypeus rather large, gently convex in profile; its apical margin always edentate and straight to weakly convex. Occipital carina sharp and narrow. Malar space about 1.0 as long as basal width of mandible. Pronotum with epomia well defined but not extending much dorsad or ventrad of scrobe. Mesoscutum with notaulus faint, traceable less than half its length; surface mat, dully shining, or sometimes polished and with numerous, small to medium sized, crowded to well separated punctures (punctures sparser in males). Mesopleuron without a ridge on prepectus below. Hind coxa with a sharp and strong subvertical groove externo-ventrally near base. Wing venation: areolet large, symmetrically to asymmetrically pentagonal, intercubiti slightly to definitely convergent dorsad, front side of areolet (2nd abscissa of radius) 0.9 to more than 1.0 as long as 1st intercubitus (mesal side of areolet); discocubitus gently arched, without a ramellus; mediella nearly straight; axillus long, diverging from anal margin of wing, as close to submediella as to anal margin. Propodeum: spiracle elongate; apical trans-carina varying from strong throughout, to strong laterad but obsolete mesad, to almost completely absent; cristae usually defined and subcrescentic to bluntly triangular (cristae often obsolete in males). First gastric tergite in female with a prominent crescentic to subtriangular basolateral flange and with the postpetiole strongly expanded but in male without a baso-lateral expansion and with the postpetiole slender; ventral longitudinal carina usually sharp throughout, dorso-lateral and dorsal carinae less well developed, weakest in males. Second gastric tergite mat with very fine and dense punctures (sparser in males) which sometimes become more widely spaced mesad and with short, recumbant, mostly overlapping setae. Ovipositor: long, sheathed portion $0.5-1.4$ as long as fore wing, gently upcurved, cylindro-compressed, its tip elongate (0.10-0.25 as high at nodus as long from nodus to apex), nodus low and without a notch, ventral valve on tip with sharp and inclivously oblique ridges. 

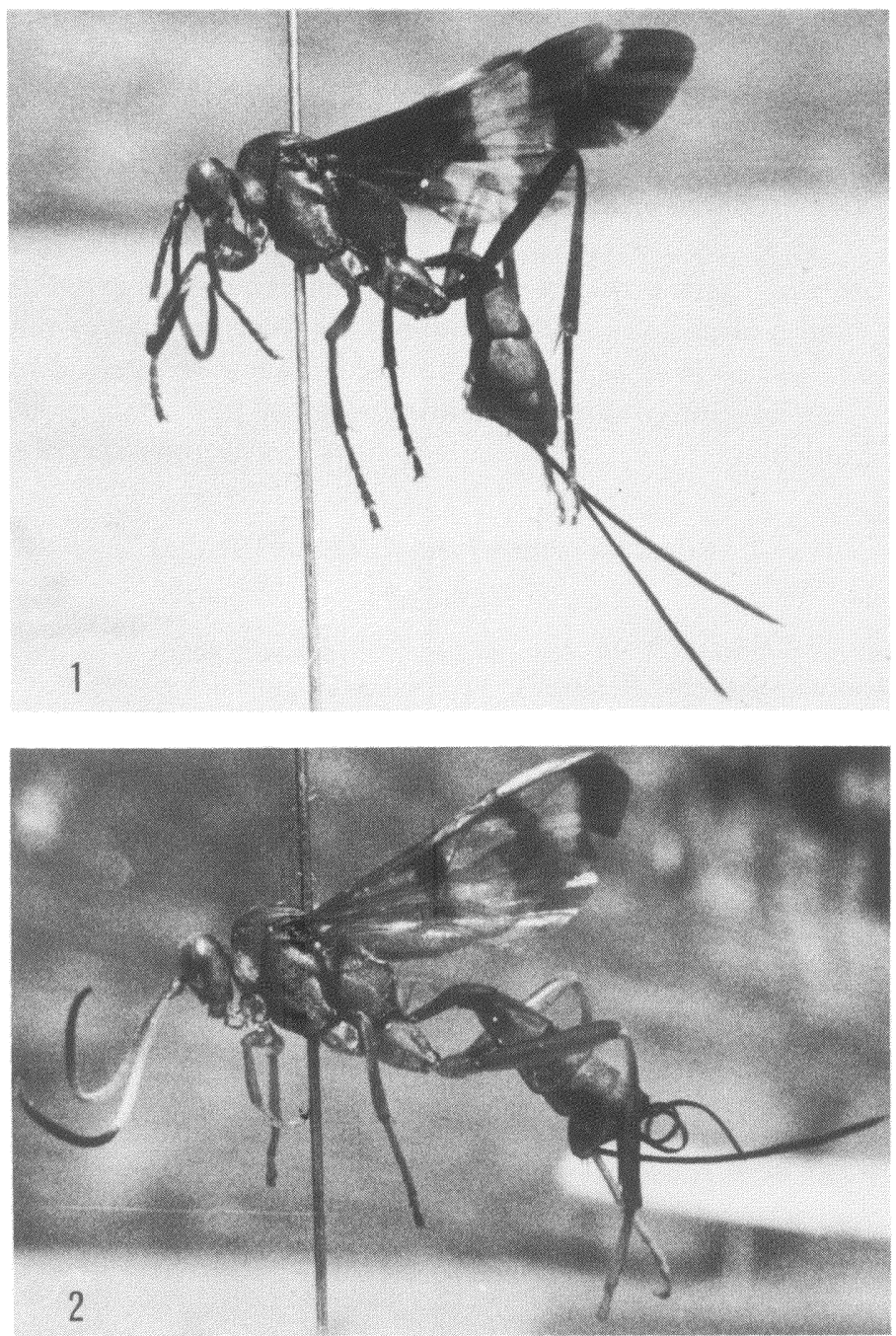

Fig. 1. Compsocryptus melanostigma, ․ Photograph of whole insect in lateral view. Fig. 2. Compsocryptus fuscofasciatus, ㅇ. Photograph of whole insect in lateral view. 
Key to the South American Species of Compsocryptus

1. Fore wing yellow with 2 narrow brown cross bands and with brown on apex; 2nd abscissa of radius $0.9-1.0$ as long as 1st intercubitus; female mesopleuron usually with some strong longitudinal wrinkling $\ldots \ldots \ldots \ldots \ldots \ldots \ldots \ldots$

.................... 1. C. fuscofasciatus (Brullé)

$1^{\prime}$. Fore wing dark brown with a broad median yellow cross band and a large subapical yellow blotch; 2nd abscissa of radius 1.2-1.5 as long as 1st intercubitus; female mesopleuron without any longitudinal wrinkling, almost uniformly punctoreticulate ............. 2. C. melanostigma (Brullé)

\section{Compsocryptus fuscofasciatus (Brullé)}

(Fig. 2, 3, 4)

Cryptus fusco-fasciatus Brullé, 1846. In Lepeletier: Histoire naturelle des insectes. Hyménoptères 4:194. Holotype o: Perú, Lima (lost).

Callicryptus ornatipennis Cameron, 1902. Trans. Amer. Ent. Soc. 28:372. Holotype

O: Perú, Callao (London).

Female. Color: antenna ferruginous on scape and pedicel, yellowish ferruginous on 1st (sometimes also 2nd and 3rd) flagellomere, mostly yellow on flagellomeres 2,3 or 4-9, brown and yellow on flagellomeres $10-11$ or 12 , and black or brownish black beyond 12th or 13th flagellomere; head ferruginous with black on apex of mandible; palpi dull ferruginous; mesosoma ferruginous with inconspicuous dusky staining on some margins and sutures or sometimes with rather extensive black markings (as described for male); gaster dull ferruginous with faint dusky staining on 2nd and following tergites or occasionally with better defined black areas toward base on 2nd and 3rd tergites; legs ferruginous, duller on tarsi, with dusky staining on apical tarsomeres, narrowly on apex of hind trochantellus and base of hind femur, and with blackish on much of hind tibia except toward its paler (sometimes contrastingly flavoferruginous) base; fore wing light yellow with three brown areas as follows: a broad transverse band on most of apical 0.3 of median cell, on base of discocubital cell, on apical 0.3 of submedian cell, on basal 0.3 of 1st brachial cell, and on adjoining region of anal cell; a second brown cross-band covering basal 0.3 of radial cell, apical 0.3 
of discocubital cell, areolet, apical 0.5 of 2 nd discoidal cell, and expanding below to cover all but basal 0.3 (or less) of 2 nd brachial cell; as well as with a third brown area on apical 0.5 of 3rd cubital cell and apical 0.5 of 3rd discoidal cell and confluent below with dark area of 2nd brachial cell; hind wing pale yellow with apical 0.3 dusky and with dusky staining prolonged more narrowly far basad on its hind margin, as well as sometimes with an irregular transverse dusky area at level of nervellus.

Length of fore wing: $10.5-12.5 \mathrm{~mm}$. Flagellum: 1st segment 3.2-3.5 as long as deep at apex; apical segments averaging 0.7-0.8 as long as wide. Malar space: 1.0 as long as basal width of mandible. Mesoscutum: dully shining with abundant, dense, sharp, tiny punctures which emit inconspicuous, short and mostly close-packed setae. Mesopleuron: surface with delicate to strong, trans-biased puncto-reticulation and, at least ventrad, usually with some strong longitudinal wrinkling. Wing venation: radial cell 3.6-4.1 as long as wide; areolet about as high as broad, symmetrically pentagonal, intercubiti weakly to moderately convergent above, 2nd abscissa of radius $0.9-1.0$ as long as 1 st intercubitus. Hind femur: 5.6-6.0 as long as deep. Hind tibia: below and laterally on apical 0.5 with a few, scattered enlarged setae. Propodeum: apical face discrete from the gently arched basal face and almost vertical; basal trans-carina traceable throughout, uniformly fine and sharp or sometimes partly weak and irregular. First gastric tergite: dorso-lateral carinae percurrent but faint; dorsal carinae well defined, but not sharp, on apex of petiole and basal 0.5 of postpetiole; surface of postpetiole mat, sometimes dully shining toward apex, with fine micro-reticulation and with tiny, sparse, shallow punctures that are best developed apico-laterad (where their short setae partially overlap). Ovipositor: sheathed portion $0.69-0.81$ as long as fore wing; tip $0.15-0.17$ as high at nodus as long from nodus to apex.

Male. Differs from female as follows: Color: pedicel sometimes marked with black; flagellomeres 1-5 (sometimes up to 9) ferruginous to yellowish with dusky staining, mostly above; at least flagellomeres 10-13 yellow with some ferruginous staining; rest of flagellum black; head ferruginous with yellowish on base of mandible, much of face laterally, and narrowly on lower 0.6 of frontal orbit as well as with black on apex of mandible, broadly above and between antennal sockets (sometimes reaching and including stem- 


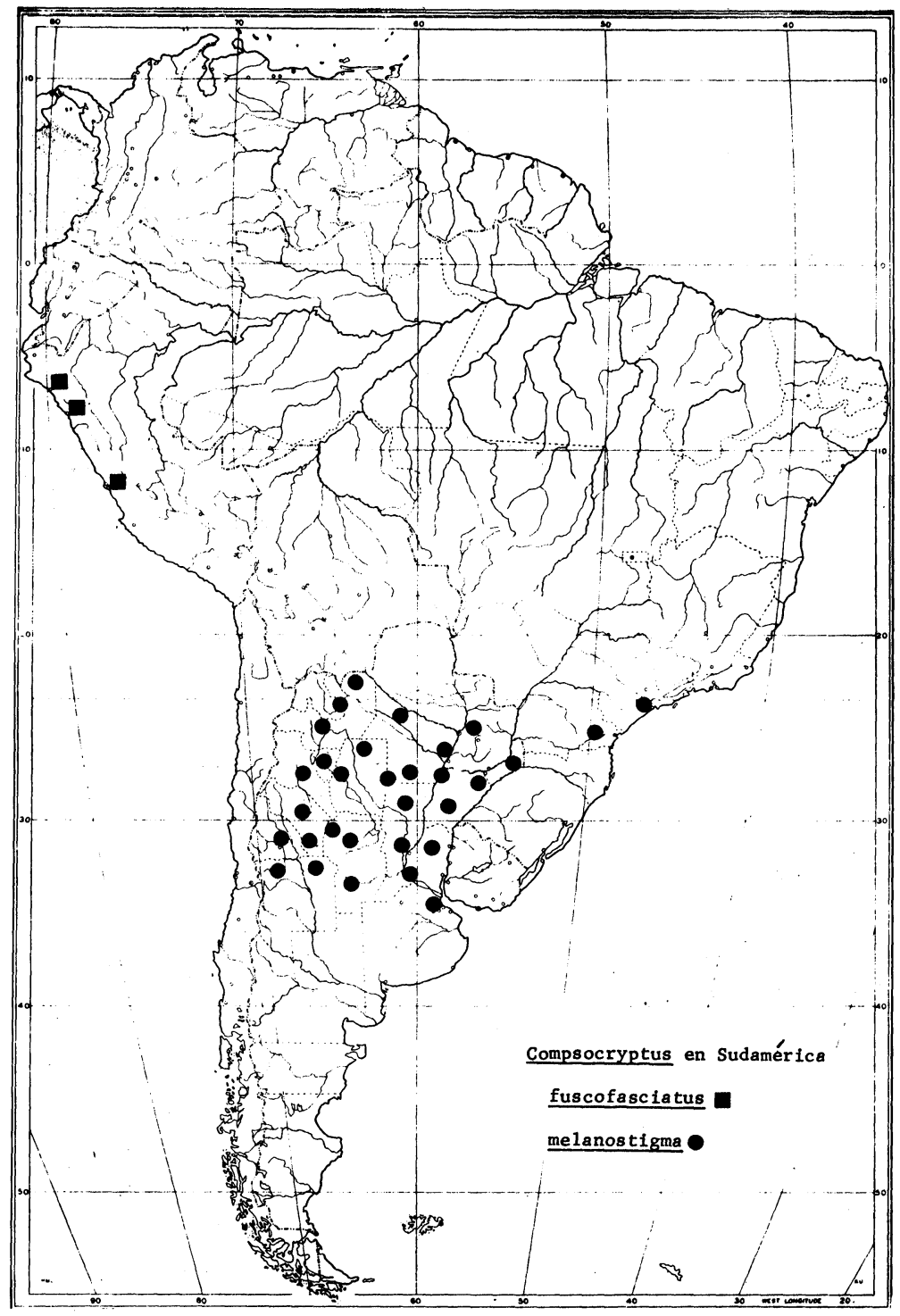

Fig. 3. Map showing geographical distribution of Compsocryptus fuscofasciatus and C. melanostigma. 
maticum) and on most of postocciput; mesosoma ferruginous with black markings usually better developed than in female and including areas on propleuron anteriorly, pronotal collar, spot on epomia (sometimes contiguous with black on collar), broad band on hind margin of pronotum, prescutellar groove, much of meso and metanotal axillary troughs, groove at base of propodeum, all of prepectus, mesosternal sulcus, hind face of mesosternum, broad band on hind margin of mesopleuron-prolonged dorsad along upper mesopleural margin to subalarum, broadly on all but dorsal margin of lower metapleuron, and irregularly on hind margin of propodeum; gaster dull to bright ferruginous with a little black at base of 1st tergite and with succeeding tergites sometimes only with irregular dusky staining and sometimes with well defined black areas toward base of tergites 2 and 3; fore and mid tibiae and tarsi more yellowish than in female; mid femur with some blackish staining dorsad and apicad; hind tibia black with basal 0.15 contrastingly pale yellow; hind tarsus blackish with light yellow at least near base of 1st segment and sometimes almost throughout on both segments 1 and 2.

Length of fore wing: $8.5-9.6 \mathrm{~mm}$. Flagellum: linear, largely percurrent tyloids present on segments 11 or 12 to 19 or $20 ; 1$ st segment 2.5-2.7 as long as deep. Malar space: $0.77-0.90$ as long as basal width of mandible. Mesoscutum: shining with abundant, moderately small, sharp punctures that are separated by 1.0-2.0 their diameters and which emit dense, erect, moderately long setae. Mesopleuron: more shining than in female, with medium sized, sharp, dense, subadjacent to reticulately confluent punctures and some longitudinally biased reticulation. Hind femur: 6.3-7.4 as long as deep. Hind tibia: with enlarged setae more abundant and conspicuous than in female. Propodeum: rather elongately convex in profile; apical face not discrete from basal; apical trans-carina weaker than in female, forming low and subcrescentic cristae or sometimes with cristae obsolete. First gastric tergite: ventro-lateral carina obsolete on petiole but sometimes becoming sharp toward apex of postpetiole; dorso-lateral and dorsal carinae in great part obsolete; surface of postpetiole smooth and shining with abundant but well separated tiny punctures that emit long and uniformly overlapping setae. 
SPecimens Examined. $15 \%$ and 47 $\hat{0}$ : PERÚ, Lambayeque Province, 33 km E. Olmos, Ruta a Jaén, 23-VII-1975, C. Porter, L. Stange; 1 km S. Lambayeque, 24-27-VII-1975, C. Porter, L. Stange; La Libertad Province, Laredo nr. Trujillo, 7-8-VII-1974, C. Porter, L. Stange; Simbal nr. Trujillo, 4-7-VII-1974, C. Porter, L. Stange; Lima Province, Cupiche, $10 \mathrm{~km}$ E. Chosica, 25-VI-2-VII-1974, C. Porter, L. Stange; Palle nr. Chosica, 17-VII-1974, C. Porter, L. Stange; San Gerónimo nr. Chosica, 28-VI-5-VII-1976, C. Porter, C. Calmbacher; nr. Surco on Carretera Central at km 59, 30-VI1976, C. Porter, C. Calmbacher.

Relationships. This Peruvian Coastal Desert endemic differs only in minor chromatic and structural features from the other South and North American Compsocryptus. It seems closely related to the Argentine $C$. melanostigma (Brullé) but may be distinguished by the following characters: (1). Fore wing yellow with two narrow brown cross bands and with brown on apex (vs. dark brown with a broad median yellow cross band and a large subapical yellow blotch), 2. Second abscissa of radius $0.9-1.0$ as long as 1st intercubitus (vs. 1.2-1.5 as long), 3. Female mesopleuron usually with some strong longitudinal wrinkling (vs. puncto-reticulate), 4. Male mesoscutum with punctures mostly separated by 1.0-2.0 their diameters (vs. 2.0 or more their diameters) and 5. Male flagellum with tyloids extending to segments 19-20 (vs. 21-23).

Field Notes. Compsocryptus fuscofasciatus has been reported only from the northern and central Peruvian Coastal Desert between Lima and Piura. Here, it frequents most well watered habitats between sealevel and $1500 \mathrm{~m}$. I have collected it along rivers and irrigation ditches in arid country as well as in orchards and degraded cloud forest. Like other Compsocryptus, this species most often occurs near or on the ground in exposed, disturbed, weedy or grassy places.

\section{Compsocryptus melanostigma (Brullé)}

(Fig. 1, 3, 5)

Cryptus melanostigma Brullé, 1846. In Lepeletier: Histoire naturelle des insectes. Hyménoptères 4:191. Lectotype \&: Brasil: "Prov. de Misiones" (Paris Museum).

Cryptus opaco-rufus Taschenberg, 1876. Ztschr. f. die Gesam. Natuw. Halle 48:64. Lectotype \&: (Brasil): Paraná (Halle). 

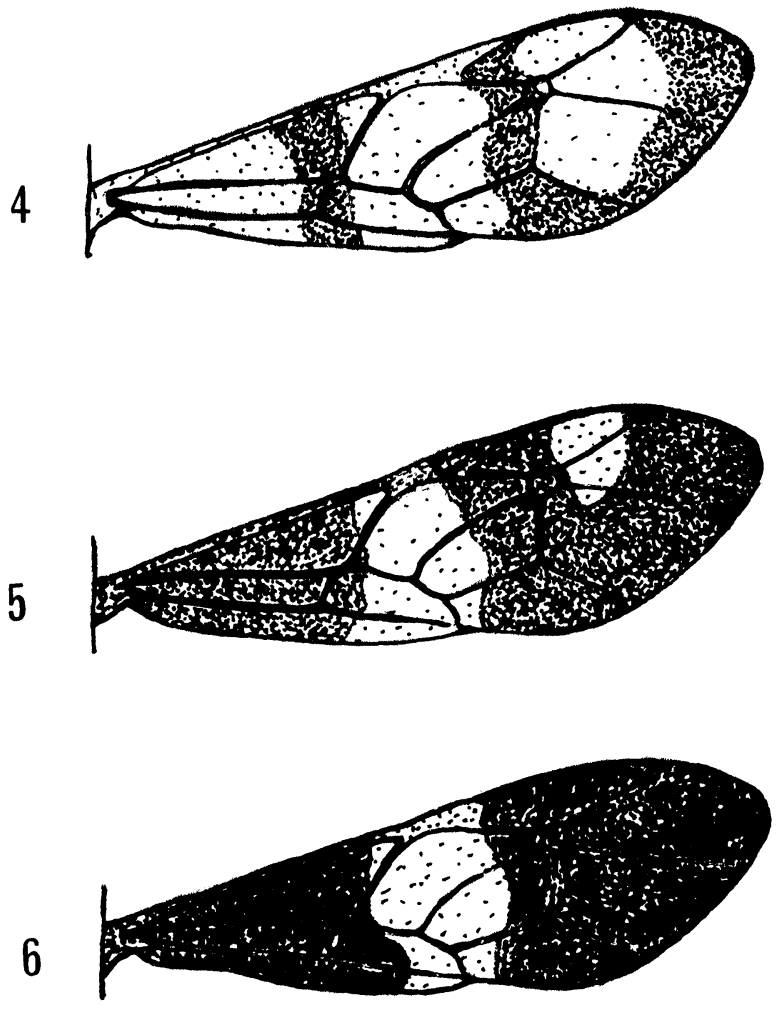

Fig. 4. Compsocryptus fuscofasciatus, ․ Fore wing, showing color pattern. Fig. 5. Compsocryptus melanostigma, ․ Fore wing, showing color pattern. Fig. 6. Compsocryptus fasciipennis, . . Fore wing, showing color pattern.

Cryptus lateritus Taschenberg, 1876. Ztschr. f. die Gesam. Naturw. Halle 48:65. Lectotype $\widehat{0}:$ (Brasil): Paraná (Halle).

Callicryptus pulchrifasciatus Cameron, 1909. Trans. Amer. Ent. Soc. 35:437. Lectotype \%: Argentina: Mendoza (London).

Sophocryptus bisulcatus Mallo, 1961. Idia 165:17. Nomen nudum.

Female. Color: antenna with scape brownish ferruginous, pedicel dusky ferruginous with apex paler, and flagellum black with 
a yellowish white annulus on segments 4 (near apex) -9; head brownish ferruginous with black on mandibular teeth; mesosoma brownish ferruginous; gaster dull brownish ferruginous with vague but often widespread dusky staining; legs brownish ferruginous with dusky on fore tibia and tarsus, mid femur dusky dorso-apicad, mid tibia extensively blackish or dusky, mid tarsus blackish brown, some dusky staining on hind trochantellus, much blackish brown (especially apicad) on hind femur, and black almost throughout on hind tibia and tarsus; wings dark brown; fore wing with a broad transverse median yellow band that covers dorso-apical corner of median cell, basal 0.6 of discocubital cell, basal 0.5 of 2 nd discoidal cell, all but base of 1 st brachial cell, basal 0.2 of 2 nd brachial cell, and anal cell beneath 1st and 2nd brachial cells, as well as with a rounded yellow blotch covering most of apical 0.5 of radial cell, a little of areolet, and basal 0.3 of 3rd cubital cell; hind wing with a very broad yellow transverse band on its postmedian 0.25 , contiguous with median yellow band of fore wing.

Length of fore wing: 10.0-12.3 mm. Flagellum: 1st segment 3.4-3.5 as long as deep at apex; apical segments $0.6-0.8$ as long as wide. Malar space: 1.0-1.1 as long as basal width of mandible. Mesopleuron: with extensive comparatively fine puncto-reticulation and without any strong longitudinal wrinkling. Wing venation: radial cell 3.8-4.5 as long as wide; areolet a little broader than high, intercubiti weakly convergent above, 2 nd abscissa of radius 1.2-1.5 as long as 1st intercubitus. Hind femur: $6.0-7.0$ as long as deep. Hind tibia: on apical 0.5 with numerous but widely spaced enlarged setae. First gastric tergite: dorso-lateral carinae often sharp on petiole; dorsal carinae varying from obsolete to weak; surface of postpetiole uniformly mat with finely granular micro-reticulation, practically glabrous, even apico-laterad. Ovipositor: sheathed portion $0.76-0.83$ as long as fore wing; tip $0.14-0.16$ as high at nodus as long from nodus to apex.

Male. Differs from female as follows: Color: scape yellow and ferruginous, pedicel brown with some yellowish apicad, flagellum with a yellowish white annulus on segments 9 or 10-12 or 13; face rather pale ferruginous with some yellowish staining or with yellow on facial orbits and less extensively also on frontal orbits; front becoming dark brown to black between and above antennal sockets; postocciput partly to mostly black; mesosoma with some black on 
propleuron, sometimes with a pair of black spots on pronotum dorsally behind collar, sometimes narrowly black on anterio-lateral margin of pronotum, sometimes narrowly black on much of hind margin of pronotum, vaguely to extensively blackish on prepectus, sometimes tinged with black in meso and metanotal axillary troughs, sometimes blackish behind subalarum, sometimes black stained in mesosternal sulcus, and sometimes blackish on margins of lower metapleuron; gaster with slight to conspicuous blackish staining, often irregularly on 2 nd tergite and always rather broadly on tergites 5-7; fore tibia and tarsus yellowish with tarsus comparatively dark and dusky on last segment; mid leg with blackish in part on trochanter and trochantellus, femur pale yellow on apical 0.2 and otherwise blackish to brownish, tibia pale yellow, and tarsus dusky with dirty yellow on basal 0.5 of first segment; hind leg with black and brown staining on trochanter and trochantellus, femur black or dark brown, and tibia black with a broad, dull yellowish-white prebasal band covering about 0.25 of segment.

Length of fore wing: $8.6-10.3 \mathrm{~mm}$. Flagellum: linear, largely percurrent tyloids present on segments 11 or $12-21,22$, or 23 ; 1 st segment 2.6-3.1 as long as deep. Malar space: $0.82-0.93$ as long as basal width of mandible. Mesoscutum: shining with abundant, small, sharp punctures that generally are separated by more than 2.0 their diameters. Mesopleuron: similar to female but with coarser, longitudinally biased wrinkling and larger intercalated punctures. Hind femur: 5.5-7.2 as long as deep. First gastric tergite: postpetiole smooth and shining with abundant but well separated tiny punctures whose setae mostly overlap laterad but become somewhat sparser toward the meson.

SPECIMENS EXAMINED. 310 and 240ึ: ARGENTINA, Formosa Province, Arroyo Eh Eh Grande, 76 km N Formosa, Rta. 11, 14-VIII-1977, C. Porter, L. Stange, P. Fidalgo, Arroyo San Hilario, 15 km S. Formosa, Rta. 11, 11-12-VIII-1977, C. Porter, L. Stange, P. Fidalgo, Riacho Pilagá, 27 km N. Formosa, Rta. 11, 12-VIII1977, C. Porter, L. Stange, P. Fidalgo; Salta Province, Dique Itiyuro, 70 km N. Tartagal, 30-VII-1977, C. Porter, L. Stange, P. Fidalgo, Tartagal, 11-18-VIII-1973, C. Porter, 10 km N. Vespucio, 12-VIII-1976, C. Porter, L. Stange, Rosario de la Frontera, 19-VI1972, C. Porter; Tucumán Province, Río Nio, 30-XI-1964, C. Porter, San Pedro de Colalao, 19-XII-1964, C. Porter, Villa Nougués, 26-27-XI-1964, 6-7-XII-1964, C. Porter; Santiago del Estero Pro- 
vince, Termas de Río Hondo, Dique Frontal, 3-V-1972, 2-VIII1973, C. Porter; La Rioja Province, Villa Unión, 22-IV-1972, C. Porter; Córdoba Province, La Lejanía ca. Nono, 23-25-X-1984, C. Porter, T. O'Neill.

Relationships. As discussed under that species, Compsocryptus melanostigma much resembles $C$. fuscofasciatus of the Peruvian Coastal Desert. The two species may have originated from a common ancestor that once ranged across what is now subtropical South America from north Argentina to the Pacific coast. Warm, seasonally dry conditions, of a type preferred by most modern Compsocryptus, apparently prevailed across this area during the early Tertiary (Solbrig 1976:42). Subsequent Andean uplift would have split early Compsocryptus, populations into eastern and western isolates, setting the stage for differentiation of the modern $C$. melanostigma in Argentina and C. fuscofasciatus in coastal Perú.

FIELD Notes. This conspicuous species occurs throughout northern Argentina below $1500 \mathrm{~m}$ and ranges into adjoining parts of Brasil and Paraguay. It occupies many forest, thorn scrub, and desert biomes, including Southeast Brasilian Wet Forest, subtropical Andean Cloud Forest, Chaco Forest, Wet Chaco, Dry Chaco, Montane Chaco, and Subandean Desert. In wooded areas, C. melanostigma prefers disturbed situations in full sun along trails or at the forest edge. In all habitats, it flies mostly near the ground among grasses, forbs, or low shrubs.

Compsocryptus melanostigma often is very common during fall and winter but may be collected in most habitats at any time of the year.

This is the only Compsocryptus for which host information has been obtained. It has been reared from the noctuid moths Alabama argillacea and Pseudaletia unipunctata (Townes 1966:77).

\section{Compsocryptus fasciipennis (Brullé)}

(Fig. 6)

Cryptus fasciipennis Brullé, 1846. In Lepeletier: Histoire naturelle des insectes. Hymenoptereś 4:191. Lectotype o (labeled by H. K. Townes Townes): Cuba (Paris).

This elegant species was well characterized by Townes (1962: 282-3). It differs from other Compsocryptus by its bluish black 
ground color; black wings with a single yellow cross band on fore wing; coarsely punctate to (medially) reticulo-punctate mesopleuron; very densely setose 2 nd gastric tergite; and sheathed portion of ovipositor averaging only 0.67 as long as fore wing.

Like the South American Compsocryptus, C. fasciipennis is isolated by more than $1000 \mathrm{~km}$ from its nearest congeners. It occurs only on the Keys and in the Everglades region of tropical Florida as well as on Cuba. Other North American Compsocryptus range both northwest and southwest from near Houston in east Texas.

Current research has added some new information on the ecology and geographic distribution of $C$. fasciipennis. These data are summarized below.

New Specimens Examined: 130 and 33ð̊: UNITED STATES, Florida, Monroe County, Bahia Honda Key State Park 11-X-1981, C. Porter, L. Stange; Big Pine Key, 16-18-V-1982, 25-X-1982, C. Porter; Fleming Key, V-1979 to V-1980, Malaise Trap, H. V. Weems, Jr.; North Key Largo, 15-V-1982, 12-X-1981, C. Porter, L. Stange; Stock Island, 18-V-1982, C. Porter, L. Stange.

FIELD Notes. Like other Compsocryptus, this species usually occurs flying close to or crawling on the ground in early secondary successional habitats at the edge of mature forests. In October of 1981 I netted 12 males from Bidens pilosa growing on the center strip of a parking lot on Bahia Honda Key. My Key Largo specimens also were taken from stands of Bidens. On Big Pine Key, I swept several $C$. fasciipennis amid herbaceous undergrowth on a sand ridge along a trail through a Tropical Hardwood Hammock.

Townes (1960:283) cites 75 males and 44 females of $C$. fasciipennis from south Florida (Miami and Everglades National Park to Key West) and indicates that the yearly activity period for this species in Florida spans "December 28 to April 12" with 1 record for 5 December. My new records show that the species begins to fly as early as 11 October and continues at least until 18 May. It is scarce in May but often becomes abundant in October (e.g., 12 $\widehat{\delta}$ from Bahia Honda Key on 11-X-1981).

The Malaise Trap records from Fleming Key elicit interest for several reasons. They are the first annual survey of Compsocryptus (and other ichneumonid) abundance done on the Florida Keys. They also provide an idea of ichneumonid species composition and density in a highly disturbed part of the Keys. Fleming Key is an artificial appendage of Key West, mainly given over to a U. S. D. A. 
animal quarantine facility and with little vegetation other than mangroves, pioneering stage herbs, and introduced ornamental trees, such as Casuarina. Such environments select for unusually hardy ichneumonids and species of this type should particularly concern the biological control specialist, who is looking for parasites that will thrive in climatically stressed agricultural systems.

The Fleming Key Survey, run between May 1979 and May 1980, with a gap in September and October, amassed 631 ichneumonid specimens belonging to 37 species. Only 9 of these species accounted for about $89 \%$ (561 specimens) of all Ichneumonidae trapped. Diadegma sp. (22 specimens) was the least abundant of the "common" group, followed by Compsocryptus fasciipennis (23), Labena grallator (36), Mallochia agenioides (41), Anomalon sp. (43), Temelucha sp. (68), Paraditremops albipectus (103), Calliephialtes ferrugineus (107), and Eiphosoma dentator (118, Porter 1983).

Table 1 summarizes monthly phaenology for Compsocryptus fasciipennis and the eight other common ichneumonid species of the depauperate Fleming Key Fauna, as sampled by Malaise traps. Compsocryptus fasciipennis is active from fall to late spring with maxima in March and October (as shown by Malaise and hand collected specimens). This seasonal phaenology coincides approximately with that of the Argentine C. melanostigma and agrees even more closely with the pattern shown by $C$. texensis in the Lower Río Grande Valley (present from January to May and again in December with greatest abundance in December, as documented by Porter, 1977:82).

Compsocryptus fasciipennis follows a cool-season phaenologic cycle not unlike that of many other ichneumonids which inhabit subtropical communities from Florida and Texas to Argentina. Among the abundant Ichneumonidae at Fleming Key, 4 species have autumn to early spring maxima and roughly parallel $C$. fasciipennis (Calliephialtes ferrugineus, Paraditremops albipectus, Temelucha sp., and Diadegma sp.), 2 peak in May (Labena grallator, Anomalon sp.), and the other 2 become most abundant during July and August (Eiphosoma dentator, Mallochia agenioides). Nonetheless January to March seem the best overall months for ichneumonids at this locality. All 9 species occur during this trimester and 230 


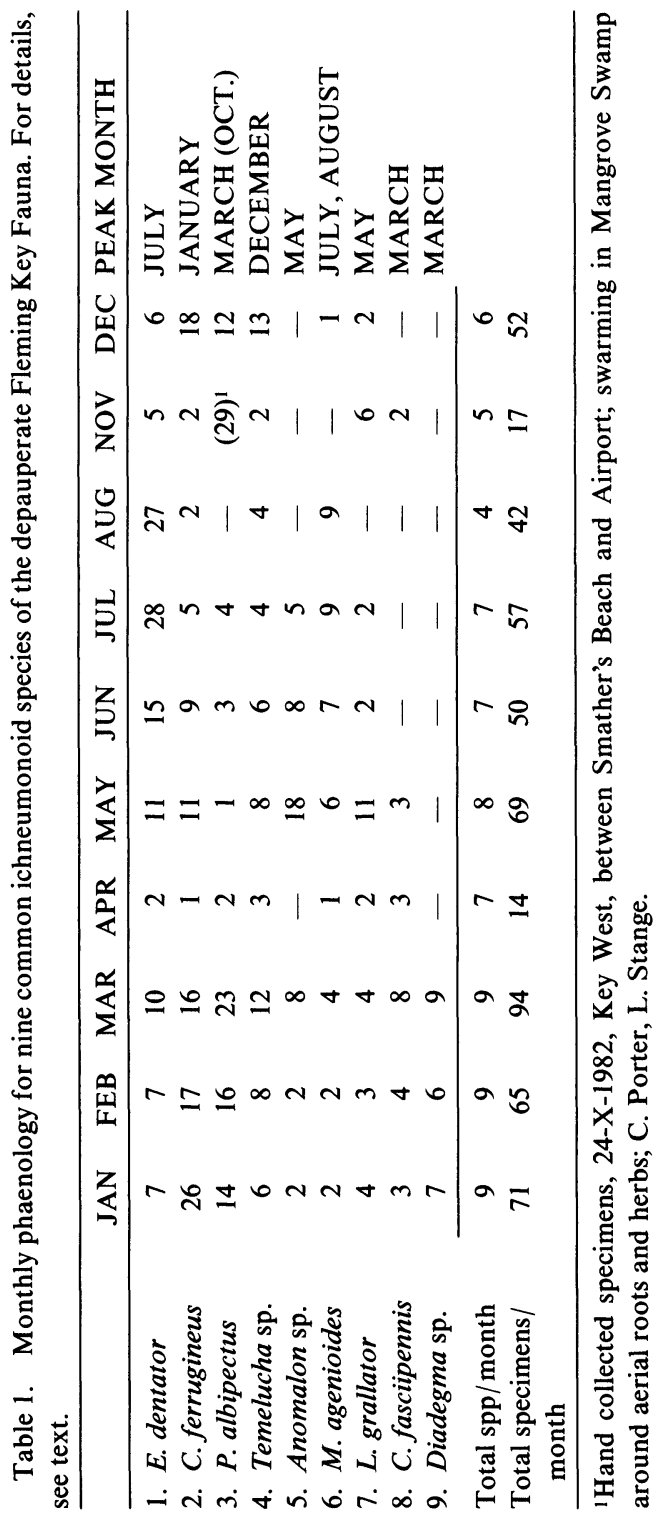


of the 561 specimens were collected then. These data agree closely with my earlier studies on south Texas mesostenine Ichneumonidae (Porter 1977), which reported peak diversity (20/34 species) and maximum abundance (138/679 specimens) for December and only slightly less impressive statistics for January (18 species and 135 specimens).

\section{ACKNOWLEDGMENTS}

This research was done principally under my current National Science Foundation Grant (BSR-8313444) and in part was supported by previous NSF awards (DEB-75-22426, GB-6925). Grants from the Committee for Research and Exploration of the National Geographic Society permitted field research in South America during 1973, 74, 75, 79, and '81. Support also came from Faculty Fellowships conferred by Fordham University for the Spring Semester of 1980 and the Fall Term of 1984.

As a Research Associate of the Florida State Department of Agriculture and Consumer Services, I have received generous support from the Division of Plant Industry at Gainesville, among whose personnel special thanks befit Dr. Howard V. Weems, Jr., Dr. Lionel A. Stange, and Mr. Harold A. Denmark. All my collecting in South Florida was facilitated by the Division of Plant Industry.

Material of Compsocryptus melanostigma was obtained in Argentina during repeated periods of cooperation with the Instituto Miguel Lillo of the Universidad de Tucumán. I am particularly indebted to Professor Rodolfo Golbach and to Dr. Abraham Willink of this institution.

I also thank Mr. Thomas J. O'Neill of Fordham University for his assistance on fieldtrips to Argentina and Perú.

\section{SUMMARY}

Compsocryptus is a mesostenine closely related to Trachysphyrus. Its short notauli, long anterior side of areolet, medially situate axillus, long and upcurved ovipositor, and (usually) dark and yellow banded wings distinguish Compsocryptus from most other trachysphyroids. There are 15 species centered in the Sonoran region of 
western North America and México plus 1 isolated species in Florida and Cuba, another in the Peruvian Coastal Desert, and a 3rd in the Argentine Chaco. Compsocryptus fuscofasciatus from Perú has the fore wing yellow with 2 brown bands, while in the Argentine C. melanostigma the fore wing is dark with a broad median yellow cross band and a large subapical yellow blotch. Townes (1962) has fully characterized the North American species. Compsocryptus inhabits a variety of exposed situations at altitudes below $1500 \mathrm{~m}$, including deserts, Thorn Scrub, Subtropical and Tropical Deciduous forests, and disturbed sites in humid Neotropic forests. The species fly mostly from fall to spring. Compsocryptus melanostigma has been reared as a solitary parasite from noctuid moth pupae.

\section{Literature Cited}

PORTER, C.

1967. A revision of the South American species of Trachysphyrus. Mem. Amer. Ent. Inst. 10:1-386.

1977. Ecology, zoogeography, and taxonomy of the Lower Río Grande Valley Mesostenines. Psyche 84(1):28-91.

1980. Zoogeografía de las Ichneumonidae latino-americanas. Acta Zool. Lilloana 36:5-52.

1983. Eiphosoma dentator in Florida. Florida Ent. 66: 353-358.

1986. Trachysphyrus and the new genus Aeliopotes in the coastal desert of Perú and North Chile. Psyche 92: 513-545.

Spencer, K. A. ANd C. E. Stegmaier, Jr.

1973. Agromyzidae of Florida. Arthropods of Florida and neighboring land areas 7:1-205. Division of Plant Industry, Gainesville.

SOLBRIG, $\mathrm{O}$.

1976. The origin and floristic affinities of the South American temperate desert and semidesert regions. In D. Goodall (ed.), Evolution of desert biota, $\mathrm{p}$. 7-49. University of Texas Press, Austin.

TOWNEs, H. K.

1962. Ichneumon-flies of America north of México: Subfamily Gelinae, Tribe Mesostenini. Bull. U. S. Natl. Mus. 216(3):1-602.

1966. A catalog and reclassification of the Neotropic Ichneumonidae. Mem. Amer. Ent. Inst. 11:1-367.

1969. Genera of Ichneumonidae, Part 2: Gelinae. Mem. Amer. Ent. Inst. 12:1-537. 

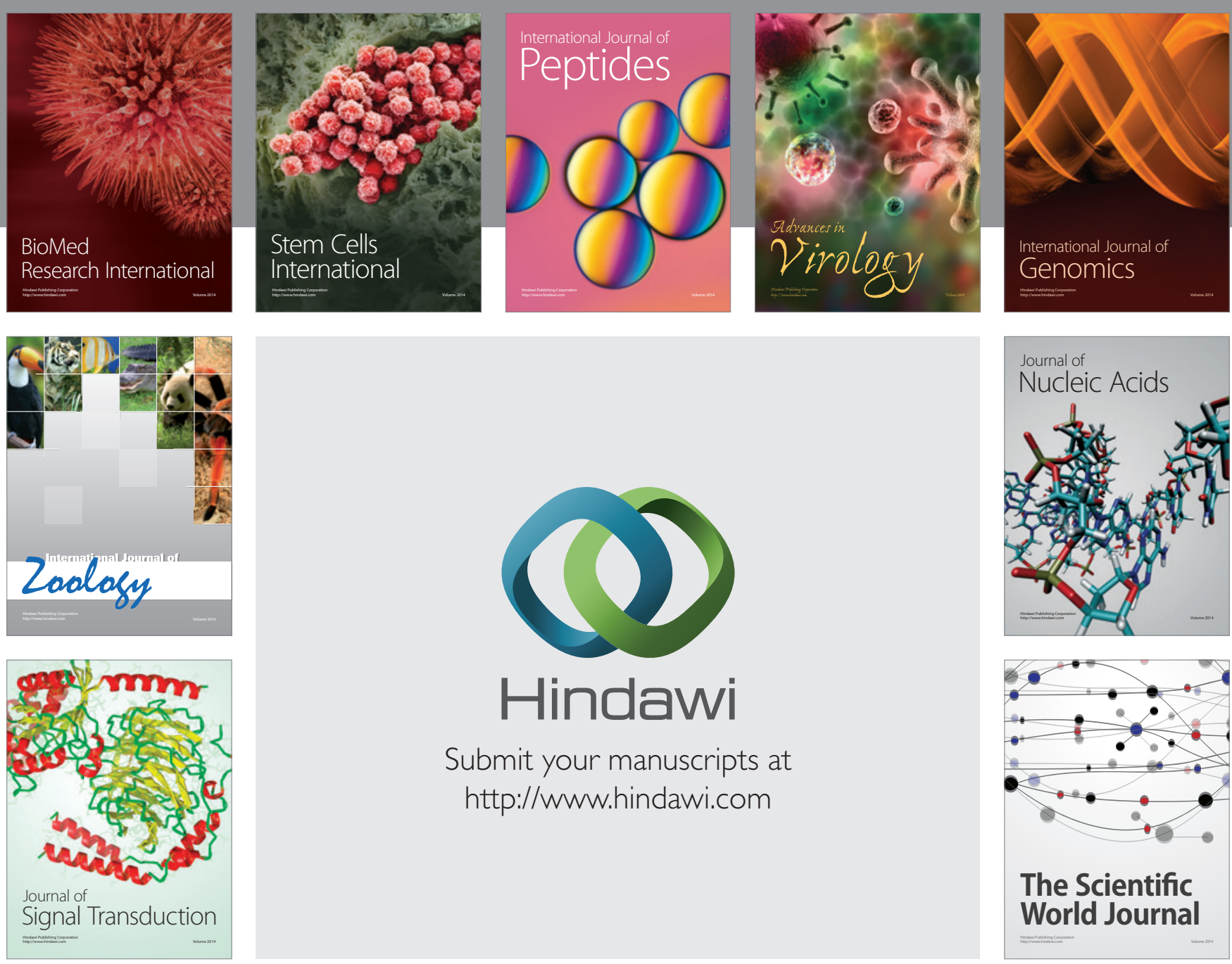

Submit your manuscripts at

http://www.hindawi.com
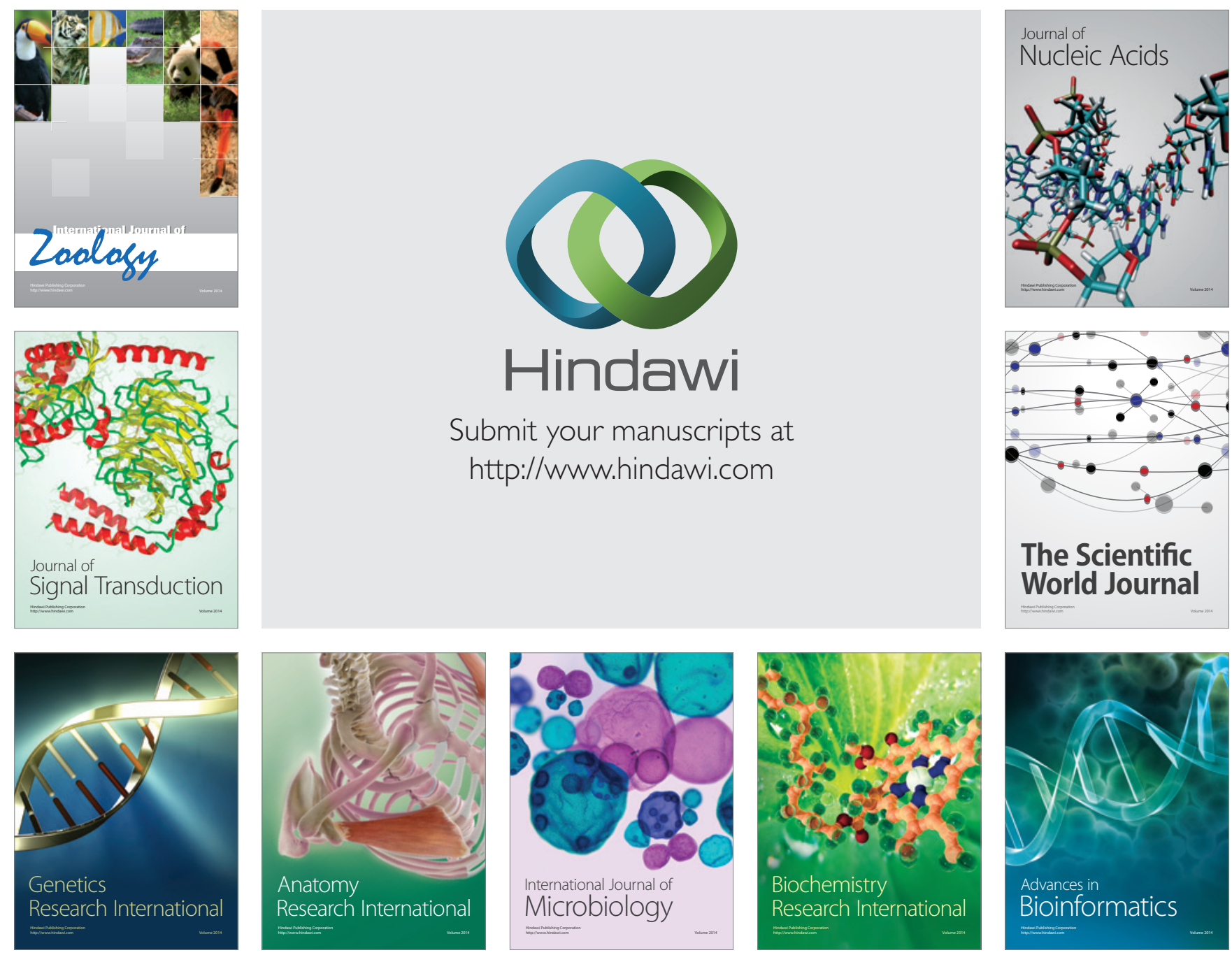

The Scientific World Journal
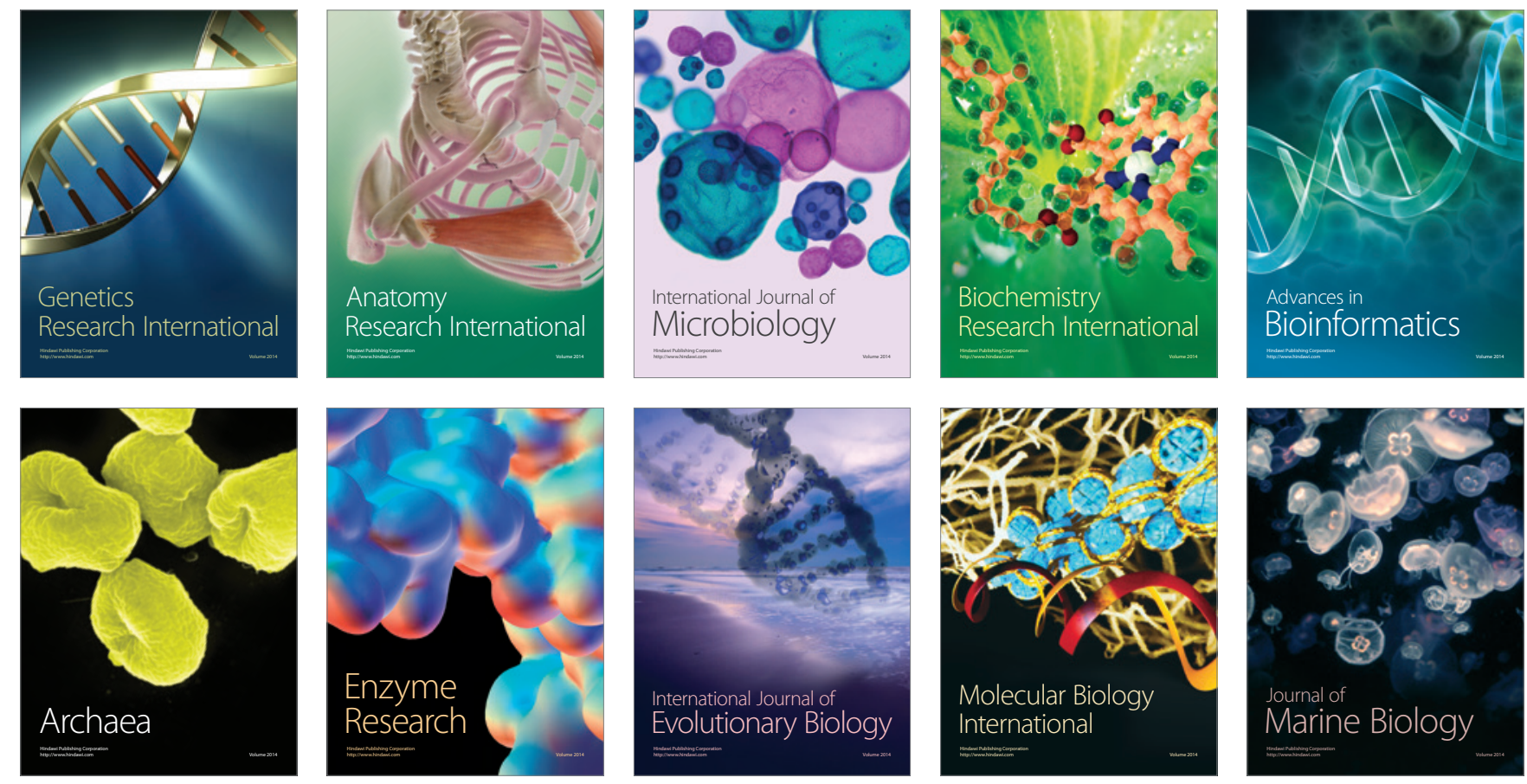